Web page: jurnal.ugm.ac.id/v3/jaci

\title{
The Roles of Pentraxin-3 to Predict In-hospital and Three Months Major Adverse Cardiac Event in Acute Myocardial Infarction
}

Adi Bestara*, Trisulo Wasyanto, Niniek Purwaningtyas

Department of Cardiology and Vascular Medicine, Faculty of Medicine, University of Sebelas Maret, Surakarta, Central Java, Indonesia.

\section{ARTICLE INFO \\ *Corresponding author email: \\ adibestara@gmail.com, \\ address: \\ Jalan Ir. Sutami No. 36A, \\ Kentingan, Surakarta, \\ Indonesia 57126 \\ Keywords: \\ acute myocardial infarction; pentraxin-3; major adverse cardiac event}

Manuscript submitted: November 13, 2019 Revised and accepted: February 9, 2020

\begin{abstract}
Background: Pentraxin-3 (PTX3) was a useful marker for localized vascular inflammation and damage in the cardiovascular system. Recent studies have shown that plasma PTX3 is elevated in patients with myocardial infarction; however, its prognostic value still remains unclear.

Aims: This study aimed to investigate the relationship between PTX3 and inhospital and three months of a major adverse cardiac event (MACE) in acute ST-elevation and non-ST-elevation myocardial infarction patients.

Methods: This cohort study conducted from September 1st, 2018 to October 31st, 2019 in Dr. Moewardi Hospital. A 144 patient were observed during hospitalization and 130 survived patient were follow up for three months. The admission PTX3 was compared between the patient with and without MACE. Higher levels of PTX3 were defined as concentrations greater than the optimal cut-off value derived from the Receiver Operating Characteristic (ROC) curve.

Results: Among patients, $43.75 \%$ was anterior STEMI, 35.42\% was inferior STEMI, and $20.38 \%$ was NSTEMI with median PTX3 level was 8.16 (0.2169.35) ng/mL. The in-hospital MACE occurred in $52 \%$ of patients, while three months of MACE occurred in 17\% patient. Patients with MACE had a higher level of PTX3 compared without MACE $(\mathrm{p}<0.001)$ during hospitalization, but not in three months follow up $(\mathrm{p}=0.408)$. Multivariate analysis also shown PTX3 was as a predictor of in-hospital MACE (OR 1.127; $\mathrm{p}=0.001$ ), along with heart rate (OR 1.025; $\mathrm{p}=0.015)$. There are different of in-hospital MACE between the patient with high $(\geq 8.247 \mathrm{ng} / \mathrm{mL})$ and low $(<8.225 \mathrm{ng} / \mathrm{mL})$ PTX3 level with a hazard ratio (HR) 2.142 (95\%CI 1.315-3.487; p=0.002), but the result did not similar after three months follow up ( $\mathrm{p}=0.373)$.
\end{abstract}

Conclusion: The PTX3 can be used as a predictor of in-hospital MACE but not for three months follow up.

\section{INTISARI}

Latar Belakang: Pentraxin-3 (PTX3) merupakan suatu petanda inflamasi dan kerusakan vaskular yang terlokalisir pada sistem kardiovaskular. Studi terkini memperlihatkan PTX3 plasma meningkat pada pasien dengan infark miokard akut, namun peran prognostiknya belum sepenuhnya diketahui.

Tujuan: Studi ini bertujuan untuk menginvestigasi hubungan antara PTX3 dengan major adverse cardiac event (MACE) pada saat hospitalisasi dan tiga bulan observasi pada pasien infark miokard akut dengan dan tanpa elevasi segmen ST

Metode: Penelitian kohort ini dilakukan pada 1 September 2018 hingga 31 Oktober 2019 di rumah sakit Dr. Moewardi. Sebanyak 144 pasien diamati 
selama hospitalisasi dan 130 pasien penyintas dilakukan observasi selama 3 bulan. PTX3 saat admisi dibandingkan antara pasien dengan dan tanpa MACE. Kadar PTX3 yang tinggi didefinisikan sebagai kadar diatas nilai titik potong teroptimal yang diperoleh dari kurva Receiver Operating Characteristic (ROC).

Hasil: Dari keseluruhan pasien, 43.75\% merupakan STEMI anterior, 35.42 merupakan STEMI inferior, dan 20.38\% merupakan NSTEMI dengan median kadar PTX3 adalah 8.16(0.21-69.35) ng/mL. MACE saat hospitalisasi terjadi pada $52 \%$ pasien, sedangkan MACE pada tiga bulan observasi terjadi pada 17\% pasien. Pasien dengan MACE memiliki kadar PTX3 yang lebih tinggi dibandingkan tanpa MACE $(\mathrm{p}<0.001)$ pada saat hospitalisasi namun tidak pada tiga bulan observasi $(\mathrm{P}=0.408)$. Analisis multivariat menunjukkan PTX3 merupakan prediktor MACE saat hospitalisasi (OR 1.127; p=0.001), bersamaan dengan laju jantung (OR 1.025; $\mathrm{p}=0.015)$. Terdapat perbedaan MACE selama hospitalisasi antara pasien dengan kadar PTX 3 tinggi $(\geq 8.247$ $\mathrm{ng} / \mathrm{mL})$ dan rendah $(<8.247 \mathrm{ng} / \mathrm{mL})$ dengan hazard ratio (HR) 2.142 (95\%CI 1.315-3.487; $\mathrm{p}=0.002$ ), namun hasil yang serupa tidak diperoleh pada observasi tiga bulan $(\mathrm{p}=0.373)$.

Kesimpulan: PTX3 dapat berguna sebagai prediktor MACE saat hospitalisasi namun tidak pada observasi tiga bulan.

\section{Introduction}

In 2018, Heart Disease and Stroke Statistics state that the prevalence of acute myocardial infarction (AMI) in the United States is around 7.9 million or about $3 \%$ of the adult population and every 40 seconds there is one person who has a heart attack. ${ }^{1}$ The incidence of heart attack is also quite high in Indonesia. The Jakarta Acute Coronary Syndrome registry study concludes that almost $11 \%$ of the population in Jakarta has an acute coronary syndrome, with $4 \%$ of them are myocardial infarction with STelevation (ST-elevation myocardial infarction [STEMI]). ${ }^{2}$ Registry data in Dr. Moewardi General Hospital, Surakarta in 2014-2018 obtained result that out of 1680 patients with acute coronary syndrome being treated, 909 (62.1\%) cases were STEMI and 296 (20.4\%) cases were NSTEMI (non-ST-elevation myocardial infarction). During hospitalization, 228 (15.9\%) patients died with the main causes of mortality being cardiogenic shock (59.9\%) and ventricular arrhythmias (25\%). ${ }^{3}$

Inflammation is the key component in the process that causes atherosclerotic plaque rupture and myocardial injury in AMI. Measurement of inflammatory biomarkers will, therefore, be an attractive choice for improving the management of AMI patients. However, the clinical value of inflammatory biomarkers is limited because many of them are less specific in the process of cardiovascular pathology and because they often only produce a less optimal prognostic value. Pentraxin-3 (PTX3) was proposed to be a promising biomarker candidate in this context. PTX3 is produced at the site of injury and can, therefore, be an important indicator for local cardiovascular inflammatory processes. ${ }^{4,5,6}$

PTX3 is a glycoprotein that was originally identified in endothelial cells from human umbilical veins and fibroblasts. PTX3 is an inflammatory protein that is widely released in vascular plaque and cardiomyocytes. ${ }^{7}$ Clinical data shows that PTX3 is a biomarker for atherosclerosis because of its role in the inflammatory process. ${ }^{8}$ Patients with susceptible coronary plaque show higher PTX3 levels compared to stable plaque. ${ }^{9}$ Patients with endothelial dysfunction show increased PTX3, and serum PTX3 levels are associated with the degree of endothelial dysfunction. ${ }^{10}$

Furthermore, PTX3 is considered a biomarker of acute myocardial injury. ${ }^{11}$ Recent studies have shown that plasma PTX3 is increased in patients with IMA. ${ }^{12}$ There is evidence of the association between PTX3 and major adverse cardiac events (MACE) in IMA patients obtained from various studies although the numbers are still limited. PTX3 has a potential role as a prognostic biomarker in IMA and its role in predicting the occurrence of MACE still requires further research. ${ }^{13}$ This study aims to determine the differences in major cardiovascular events between patients with high and low PTX3 levels at the time of hospitalization and three months of observation in IMA.

\section{Methods}

This research is an analytic cohort study conducted at the Dr. Moewardi General Hospital, Surakarta, Central Java, and the community according to the residence of the research subjects within a period of 14 months (September 1st 2018 to October 31st 2019). Patients were selected consecutively who met the inclusion criteria which was the acute myocardial infarction patients (based on complaints of angina chest pain accompanied by an increase in cardiac enzymes both with ST-segment elevation or without ST-segment elevation) with onset of symptoms $\leq 24$ hours according to guidelines by the European Society of Cardiology (ESC) and the American Heart Association (AHA) ${ }^{14,15,16}$, aged between 18-75 years, and willing to be the subject of research. Exclusion criteria in this study were a history of AMI or previously 
diagnosed heart failure, a history of moderate-severe heart valve disease, acute or sepsis infection, chronic kidney failure, liver cirrhosis, malignancy, acute stroke, and autoimmune disease.

Data was collected in the form of demographic characteristics, risk factors, medical history, physical examination, electrocardiography, and blood sampling for PTX3 examination and other laboratories when patients were administered through the antecubital vein and then sent to the Clinical Pathology Laboratory of Dr. Moewardi General Hospital. Centrifugation of blood samples for 15 minutes at a speed of 5000 rotation per minute was done to get blood serum.The blood serum is stored in a microtube and then frozen at $-800 \mathrm{C}$ until the assay. PTX3 plasma was measured by the Sandwich-enzyme-linked immunoabsorbent assay (Sandwich-ELISA) method (Human PTX3 / TSG-14 (Pentraxin 3) ELISA kit, Elabscience, Hubei, China). The micro ELISA plate has been pre-coated with an antibody specific to Human PTX3/TSG-14. Standards or samples are added to the micro ELISA plate wells and combined with the specific antibody. Then a biotinylated detection antibody specific for Human PTX3/TSG-14 and Avidin-Horseradish Peroxidase (HRP) conjugate are added successively to each microplate well and incubated. Free components are washed away. The substrate solution is added to each well. Only those wells that contain Human PTX3/TSG-14, biotinylated detection antibody and Avidin-HRP conjugate will appear blue in color. The enzyme-substrate reaction is terminated by the addition of stop solution and the color turns yellow. The optical density (OD) is measured spectrophotometrically at a wavelength of $450 \mathrm{~nm} \pm 2 \mathrm{~nm}$. The OD value is proportional to the concentration of Human PTX3/TSG-14. Calculation of the concentration of Human PTX3/TSG-14 in the samples was done by comparing the OD of the samples to the standard curve.

In addition, echocardiographic data collection, therapy, and the presence of MACE during hospitalization were done. Observations three months after hospitalization were carried out by tracing medical records, telephone calls, or home visits. The presence of major adverse cardiac events (MACE) during the period of hospitalization is defined as the presence of at least one of the following events: death, cardiopulmonary resuscitation (CPR), cardiogenic shock (Killip class IV), acute heart failure (Killip class II-III), and arrhythmias (sustained ventricular tachycardia, ventricular fibrillation, new atrial fibrillation).$^{17}$ Meanwhile, clinical outcomes that will be observed at three months of observation are death, acute nonfatal coronary syndrome, and the incidence of nonfatal heart failure that requires re-hospitalization. ${ }^{12,18}$

Statistical analysis was performed using Statistical Package for Social Sciences (SPSS) 22 (IBM, Chicago, USA). The normality of the data distribution was tested on continuous variables with the KolmogorovSmirnov test. Chi-square test or Fisher's exact test was used to compare 2 categorical variables. The Pearson or Spearman correlation test is used to compare data with variables between 2 numerical variables. Independent $t-$ test or Mann Whitney test is used to compare data with categorical variables with numeric. Furthermore, bivariate and multivariate logistic regression analyses were carried out by including significant parameters in the univariate analysis or parameters that the researchers said were biologically relevant. The optimal cut-off point value of PTX3 to predict MACE during hospitalization was analyzed with a receiver operating characteristic (ROC) curve. PTX3 levels are considered high if more than the cutoff value and vice versa. Also, the analysis of survival using the log-rank test on the Kapplan-Meier curve was done. A value of $p<0.05$ was considered to indicate a significant difference. ${ }^{19}$ This research has obtained ethical clearance approval from the Ethics Commission of Dr. Moewardi General Hospital with reference number 1.093/IX/HREC/2019.

Result

There were 144 AMI patients who became the subjects of the study. During the hospitalization, 74 subjects were included in the group with high PTX3 levels and 73 subjects with low PTX3 levels then MACE was observed. Subjects who survived during the hospitalization (130 subjects) were then grouped according to PTX3 levels (63 subjects included in the group with high PTX3 levels and 67 subjects with low PTX3 levels) and MACE was observed in a period of 3 months (Figure 1 ).

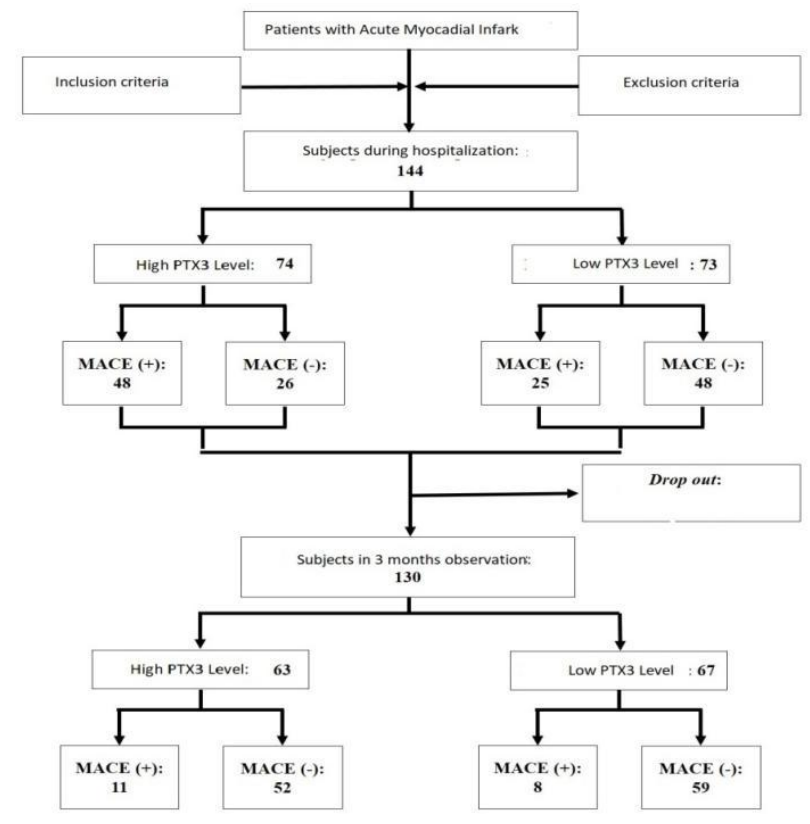

Figure 1. Research profile

The mean age of patients was $58.5 \pm 9.5$ years, and 108 $(75.0 \%)$ patients were male. The distribution of data of PTX3 levels in total subjects was 8.16 (0.21-69.35) ng / mL. During hospitalization, MACE occurred in 52\% of subjects, with the respective proportions for acute heart failure, death, arrhythmia, cardiogenic shock, and cardiopulmonary resuscitation of $32.8 \%, 9 \%, 7 \%, 4 \%$, and $1 \%$. At three months of observation, MACE occurred in 
$17 \%$ of subjects, with the proportion of deaths, the incidence of heart failure, and recurrent acute coronary syndromes at $8 \%, 6 \%$, and $3 \%$ (Figure 2). A total of $43.75 \%$ of patients were diagnosed with anterior STEMI, $35.42 \%$ inferior STEMI, and $20.83 \%$ NSTEMI. There were significant differences in MACE between the STEMI and NSTEMI groups at the time of hospitalization, but not at 3 months of observation (Table 1). Further analysis among the STEMI group receiving fibrinolytic therapy, without fibrinolytic, and NSTEMI patients are presented in supplementary data 1 .
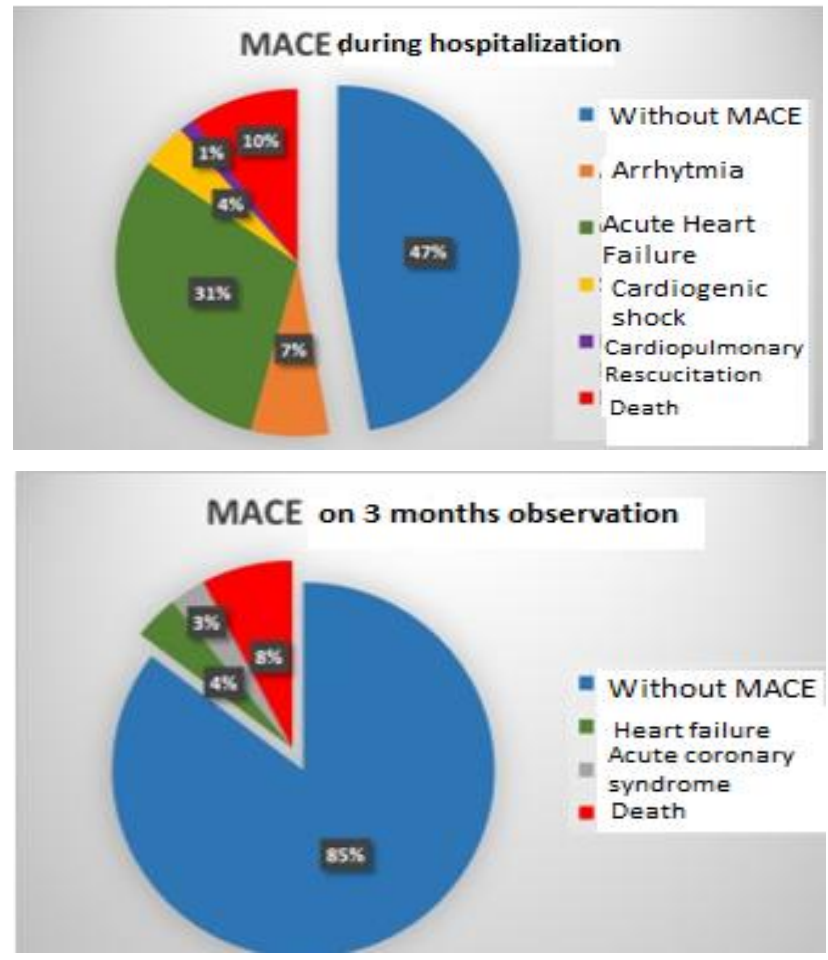

Figure 2. The proportion of MACE at hospitalization and 3 months of observation

During hospitalization, there were no significant differences in sex, type of myocardial infarction, risk factors for AMI (diabetes mellitus, hypertension, smoking status, dyslipidemia, family history of CAD (coronary artery disease), history of stroke, and body mass index, blood pressure, left ventricular ejection fraction (LVEF) and laboratory examination values (except PTX3 and eGFR [estimated glomerular filtration rate]) between patients with and without MACE. Compared to patients without MACE, patients with MACE at hospitalization had a proportion of PTX3 levels $\geq 8.247 \mathrm{ng} / \mathrm{mL}$ with a significant difference $(\mathrm{p}<0.001)$. In addition, patients with MACE had an older median age ( $p=0.039)$, a higher GRACE score $(p=0.002)$, a faster heart rate $(p=0.009)$, and lower eGFR levels $(\mathrm{p}=0.001)$. Whereas at 3 months of observation, significant parameters of MACE were length of stay $(p=0.017)$, onset of chest pain $(p=0.038)$, heart rate $(p=0.016)$, and eGFR $(p=0.002)$ (Table 2$)$.
Tabel 1. The characteristics of research subjects

\begin{tabular}{|c|c|c|c|}
\hline Variable & $\begin{array}{l}\begin{array}{l}\text { STEMI } \\
(\mathrm{n}=114 ; \\
79.2 \%)\end{array}\end{array}$ & $\begin{array}{l}\text { NSTEMI } \\
(\mathrm{n}=30 ; 20.8 \%)\end{array}$ & $P$ \\
\hline Age (years) & $57(37-75)$ & $62(47-75)$ & 0.024 \\
\hline Gender & & & \\
\hline Male, n (\%) & 93 (81.58) & $15(50)$ & $<0.001$ \\
\hline Female, n (\%) & $21(18.42)$ & $15(50)$ & \\
\hline Length of stay (days) & $5(1-22)$ & $5(1-9)$ & 0.979 \\
\hline $\begin{array}{l}\text { Onset of chest } \\
\text { pain (hours) }\end{array}$ & $6(1-24)$ & $7.5(1.5-24)$ & 0.107 \\
\hline GRACE score & 108 (39-209) & $113(60-150)$ & 0.701 \\
\hline Diabetes mellitus, n (\%) & $38(33.33)$ & $18(60)$ & 0.008 \\
\hline Hypertension, n (\%) & $72(63.16)$ & $24(80)$ & 0.082 \\
\hline Dyslipidemia, n (\%) & $59(51.75)$ & $12(40)$ & 0.252 \\
\hline Smoking, n (\%) & $78(68.42)$ & $13(43.33)$ & 0.011 \\
\hline $\begin{array}{l}\text { Family history of CAD, } \\
\mathrm{n}(\%)\end{array}$ & $6(5.26)$ & $1(3.33)$ & 0.662 \\
\hline Stroke history, n (\%) & $3(2.63)$ & $5(16.67)$ & 0.003 \\
\hline Body mass & $23.40 \quad(17.0 \mathrm{C}$ & 22.60 & 0.049 \\
\hline index $(\mathrm{kg} / \mathrm{m} 2)$ & 29.80) & $(18.70-27.30)$ & \\
\hline $\begin{array}{l}\text { Blood pressure } \\
(\mathrm{mmHg})\end{array}$ & & & \\
\hline Sistolic (mmHg) & $139.47 \pm 27.60$ & $139.47 \pm 24.21$ & 0.185 \\
\hline Diastolic (mmHg) & $80(40-128)$ & $80(39-120)$ & 0.739 \\
\hline $\begin{array}{l}\text { Heart rate } \\
\text { (beat/minute) }\end{array}$ & $78.40 \pm 20.71$ & $82.40 \pm 19.18$ & 0.342 \\
\hline Killip at admission & & & 0.025 \\
\hline Killip I, n (\%) & 87 (76.32) & $18(60)$ & \\
\hline Killip II, n (\%) & $20(17.54)$ & $9(30)$ & \\
\hline Killip III, n (\%) & $1(0.88)$ & $2(6.67)$ & \\
\hline Killip IV, n (\%) & $6(5.26)$ & $1(3.33$ & \\
\hline Killip $\geq$ II, n (\%) & $35(30.70)$ & $14(46.67)$ & 0.107 \\
\hline LVEF (\%) & $45(18-74)$ & $44(26-70)$ & 0.604 \\
\hline PTX3 (ng/mL) & $\begin{array}{l}8.16 \\
(0.88-50.01)\end{array}$ & $\begin{array}{l}7.29 \\
69.35)\end{array}$ & 0.644 \\
\hline Hs Troponin I (ng/L) & $4235(2-40000$ & $391(7-40000)$ & 0.001 \\
\hline Haemoglobine (g/dl) & $13.8(8.7-17.9)$ & $11.7(8.6-15.0)$ & $<0.001$ \\
\hline $\begin{array}{l}\text { Leukocyte (x103 } \\
\text { /mm-3) }\end{array}$ & $10.5(11-22)$ & $\begin{array}{l}9.950 \\
(6.2-20.6)\end{array}$ & 0.289 \\
\hline Platelet (x103/mm-3) & $\begin{array}{l}254(120- \\
287.6)\end{array}$ & $269(171-404)$ & 0.162 \\
\hline eGFR (mL/minute) & $70.88 \pm 29.85$ & $50.55 \pm 32.00$ & 0.001 \\
\hline $\begin{array}{l}\text { Random blood } \\
\text { sugar }(\mathrm{mg} / \mathrm{dL})\end{array}$ & $154(52-462)$ & $143(56-531)$ & 0.428 \\
\hline $\begin{array}{l}\text { Total Cholesterol } \\
\text { (mg/dL) }\end{array}$ & $187.66 \pm 40.00$ & $173.48 \pm 58.54$ & 0.257 \\
\hline $\mathrm{LDL}(\mathrm{mg} / \mathrm{dL})$ & $129.35 \pm 36.04$ & $127.59 \pm 53.15$ & 0.872 \\
\hline $\mathrm{HDL}(\mathrm{mg} / \mathrm{dL})$ & $39.66 \pm 9.03$ & $37.19 \pm 10.21$ & 0.218 \\
\hline Trigliseride $(\mathrm{mg} / \mathrm{dL})$ & $142(47-405)$ & $117(53-243)$ & 0.029 \\
\hline $\begin{array}{l}\text { MACE during } \\
\text { hospitalization, n (\%) }\end{array}$ & $53(46.5)$ & $20(66.7)$ & 0.049 \\
\hline Arrhythmia, n (\%) & $26(22.80)$ & $5(16.70)$ & 0.467 \\
\hline $\begin{array}{l}\text { Acute heart failure, } \mathrm{n} \\
(\%)\end{array}$ & $42(36.80)$ & $17(56.70)$ & 0.049 \\
\hline $\begin{array}{l}\text { Cardiogenic shock, } n \\
\text { (\%) }\end{array}$ & $14(12.30)$ & $3(10)$ & 0.731 \\
\hline CPR, n (\%) & $13(11.40)$ & $3(10)$ & 0.828 \\
\hline Death, n (\%) & $11(9.60)$ & $3(10)$ & 0.954 \\
\hline $\begin{array}{l}\text { MACE at } 3 \text { months of } \\
\text { observation, } n(\%)\end{array}$ & $15(14.60)$ & $4(14.81)$ & 0.974 \\
\hline $\begin{array}{l}\text { Acute heart failure, } \mathrm{n} \\
(\%)\end{array}$ & $5(4.85)$ & $3(11.11)$ & 0.229 \\
\hline $\begin{array}{l}\text { Acute coronary } \\
\text { syndrome, } \mathrm{n}(\%)\end{array}$ & $4(3.88)$ & 0 & 0.298 \\
\hline Death, n (\%) & $8(7.77)$ & $2(7.41)$ & 0.950 \\
\hline
\end{tabular}


Table 2.

Comparison of basic characteristics of patients based on MACE

\begin{tabular}{|c|c|c|c|c|c|c|}
\hline \multirow[b]{2}{*}{ Variable } & \multicolumn{2}{|c|}{ MACE during hospitalization } & \multirow[b]{2}{*}{$\mathrm{p}$} & \multicolumn{2}{|c|}{ MACE at 3 months of observation } & \multirow[b]{2}{*}{$\mathrm{p}$} \\
\hline & $\begin{array}{l}\text { MACE }(+) \\
(n=73 ; 50.7 \%)\end{array}$ & $\begin{array}{l}\text { MACE }(-) \\
(n=71 ; 49.3 \%)\end{array}$ & & $\begin{array}{l}\text { MACE }(+) \\
(\mathrm{n}=19 ; 14.6 \%)\end{array}$ & $\begin{array}{l}\text { MACE }(-) \\
(\mathrm{n}=111 ; 85.4 \%)\end{array}$ & \\
\hline $\begin{array}{l}\text { Age (years) } \\
\text { Gender }\end{array}$ & $60(40-75)$ & $57(37-75)$ & 0.039 & $57(43-75)$ & $58(37-75)$ & 0.257 \\
\hline $\begin{array}{l}\text { Male, n (\%) } \\
\text { Female, n (\%) }\end{array}$ & $\begin{array}{l}53(72.6) \\
20(27.4)\end{array}$ & $\begin{array}{l}55(77.5) \\
16(22.5)\end{array}$ & 0.501 & $\begin{array}{l}5(26.3) \\
14(73.7)\end{array}$ & $\begin{array}{l}26(23.4) \\
85(65.4)\end{array}$ & 0.786 \\
\hline Length of stay (days) & $5(1-22)$ & $5(3-10)$ & 0.299 & $7(1-9)$ & $5(3-22)$ & 0.017 \\
\hline Onset of chest pain (hours) & $6.5(1-24)$ & $6(1-24)$ & 0.496 & $13(2-24)$ & $6(1-24)$ & 0.038 \\
\hline GRACE score & $117(39-209)$ & $106(50-187)$ & 0.002 & $113(63-187)$ & $108(39-198)$ & 0.364 \\
\hline AMI type & & & & & & \\
\hline $\begin{array}{l}\text { STEMI, n (\%) } \\
\text { NSTEMI, n (\%) }\end{array}$ & $\begin{array}{l}53(72.6) \\
20(27.4)\end{array}$ & $\begin{array}{l}61(85.9) \\
10(14.1)\end{array}$ & 0.078 & $\begin{array}{l}15(78.9) \\
4(21.1)\end{array}$ & $\begin{array}{l}88(79.3) \\
23(20.7)\end{array}$ & 1.000 \\
\hline Diabetes mellitus, n (\%) & $23(31.5)$ & $33(46.5)$ & 0.065 & $8(42.1)$ & $45(40.5)$ & 0.898 \\
\hline Hipertension, n (\%) & $48(65.8)$ & $48(67.6)$ & 0.814 & $14(73.7)$ & $76(68.5)$ & 0.649 \\
\hline Dislipidemia, n (\%) & $33(45.2)$ & $38(53.5)$ & 0.318 & $9(47.4)$ & $61(55)$ & 0.540 \\
\hline Smoking, n (\%) & $46(63)$ & $45(63.4)$ & 0.964 & $13(68.4)$ & $71(64)$ & 0.707 \\
\hline Family history of CAD, $\mathrm{n}(\%)$ & $2(2.7)$ & $5(7)$ & 0.230 & 0 & $7(6.3)$ & 0.260 \\
\hline Stroke history, n (\%) & $3(4.1)$ & $5(7)$ & 0.442 & $2(10.5)$ & $6(5.4)$ & 0.391 \\
\hline $\begin{array}{l}\text { Body mass index }(\mathrm{kg} / \mathrm{m} 2) \\
\text { Blood pressure }(\mathrm{mmHg})\end{array}$ & $23.10(18.71-29.80)$ & $23.10(17-28.5)$ & 0.864 & $22.8(19-27.3)$ & $23.28(17-29.8)$ & 0.442 \\
\hline Sistolic (mmHg) & $132(70-204)$ & $130(90-210)$ & 0.660 & $140(73-166)$ & $131(70-210)$ & 0.509 \\
\hline Diastolic (mmHg) & $80.45 \pm 17.92$ & $80.13 \pm 15.10$ & 0.906 & $82.15 \pm 17.33$ & $80.13 \pm 15.08$ & 0.477 \\
\hline Heart rate (beat/minute) & $83.56 \pm 22.72$ & $74.79 \pm 16.73$ & 0.009 & $83.14 \pm 22.32$ & $74.79 \pm 16.73$ & 0.016 \\
\hline LVEF (\%) & $40(18-74)$ & $47(29-72)$ & 0.067 & $37(18-64)$ & $46(25-74)$ & 0.050 \\
\hline PTX3 (ng/mL) & $9.39(21-69.35)$ & $4.69(0.88-21.17$ & l $<0.001$ & $8.88(1-24.49)$ & $7.93(0.21-69.35)$ & 0.408 \\
\hline Hs Troponin I (ng/L) & $2220(6-40000)$ & $2014(2-40000)$ & 0.658 & $2275(75-40000)$ & $1890(2-40000)$ & 0.956 \\
\hline Haemoglobin $(\mathrm{g} / \mathrm{dl})$ & $13(8.6-17.9)$ & $13.8(8.7-17.3)$ & 0.052 & $13.4(8.6-16)$ & $13.5(8.7-17.9)$ & 0.637 \\
\hline Leukocyte (x103/mm-3) & $10.25(1.6-22)$ & $10.3(1.1-18.9)$ & 0.680 & $10(1.3-14.2)$ & $10.1(1.1-18.9)$ & 0.668 \\
\hline Platelet (x103/mm-3) & $264.5(267-287.6)$ & $250(120-463)$ & 0.137 & $240(256-408)$ & $259.5(120-287.6)$ & 0.274 \\
\hline eGFR (mL / minute) & $58.04 \pm 28.42$ & $75.48 \pm 31.87$ & 0.001 & $58.33 \pm 28.32$ & $75.48 \pm 31.87$ & 0.002 \\
\hline Random Blood sugar (mg / dL) & $146(56-531)$ & $166(52-423)$ & 0.093 & $125(86-328)$ & $150(52-531)$ & 0.270 \\
\hline Total cholesterol (mg / dL) & $180.59 \pm 45.70$ & $188.63 \pm 43.23$ & 0.296 & $180.29 \pm 45.18$ & $188.63 \pm 43.23$ & 0.287 \\
\hline $\mathrm{LDL}(\mathrm{mg} / \mathrm{dL})$ & $126.06 \pm 42.32$ & $131.65 \pm 37.54$ & 0.418 & $126 \pm 42.95$ & $131.65 \pm 37.54$ & 0.427 \\
\hline HDL (mg/dL) & $38.55 \pm 9.53$ & $39.72 \pm 9.10$ & 0.467 & $38.09 \pm 9.31$ & $71 \pm 9.1$ & 0.318 \\
\hline Trigliseride (mg/dL) & $121(47-376)$ & $144(57-405)$ & 0.160 & $118(47-367)$ & $142(56-405)$ & 0.192 \\
\hline
\end{tabular}

Multivariate analysis of significant parameters in the bivariate test showed that PTX3 (OR 1.127; $\mathrm{p}=0.001$; 95\% CI 1.050-1.210) along with heart rate (OR 1.025; $\mathrm{p}=$ $0.015 ; 95 \%$ CI 1.005-1.046) were independent predictors of occurrence MACE during hospitalization (Table 3). The findings of multivariate analysis in the 3-month observation period showed that eGFR was an independent predictor of MACE (OR 1.018; $p=0.046$; 95\% CI 1.0001.037) (Table 4).

Table 3.

Multivariate analysis to predict MACE at hospitalization

\begin{tabular}{llll}
\hline Variable & OR & $\mathrm{p}$ & $95 \% \mathrm{CI}$ \\
\hline Age & 1.013 & 0.601 & $0.965-1.063$ \\
GRACE score & 1.012 & 0.106 & $0.997-1.027$ \\
Heart rate & 1.025 & $0.015^{*}$ & $1.005-1.046$ \\
(beats / minutes) & & & \\
PTX3 (ng / mL) & 1.127 & $0.001^{*}$ & $1.050-1.210$ \\
eGFR & 0.986 & 0.057 & $0.986-0.972$ \\
\hline
\end{tabular}

Table 4.

Multivariate analysis to predict MACE at 3 months of observation

\begin{tabular}{llll}
\hline Variable & OR & $\mathrm{p}$ & $95 \% \mathrm{CI}$ \\
\hline Length of Stay (days) & 0.875 & 0.220 & $0.706-1.083$ \\
$\begin{array}{l}\text { Heart rate } \\
\text { (beats / minutes) }\end{array}$ & 0.995 & 0.722 & $0.971-1.021$ \\
$\begin{array}{l}\text { Onset of chest pain (hour0.955 } \\
\text { eGFR }\end{array}$ & 0.055 & $0.911-1.001$ \\
\hline
\end{tabular}

The diagnostic analysis was performed using a Receiving Operating Characteristic (ROC) curve to determine discrimination based on the area under the curve (Area Under the Curve [AUC]) between PTX3, heart rate, and the combination of PTX3 and heart rate in predicting MACE during hospitalization (Figure 3 and Table 5). ROC curves of PTX3 levels have AUC of $67.4 \%$ ( $p<0.001 ; 95 \%$ CI 0.586-0.762) and if merging of PTX3 levels with heart rate was done, it will produce a better diagnostic profile in predicting MACE during hospitalization with AUC of $71.9 \%$ ( $p<0.00195 \%$ CI $0.637-0.801$ ). At 3 months of observation, no further testing of PTX3 levels was used using the ROC curve because no significant results were obtained in bivariate or multivariate analysis. 


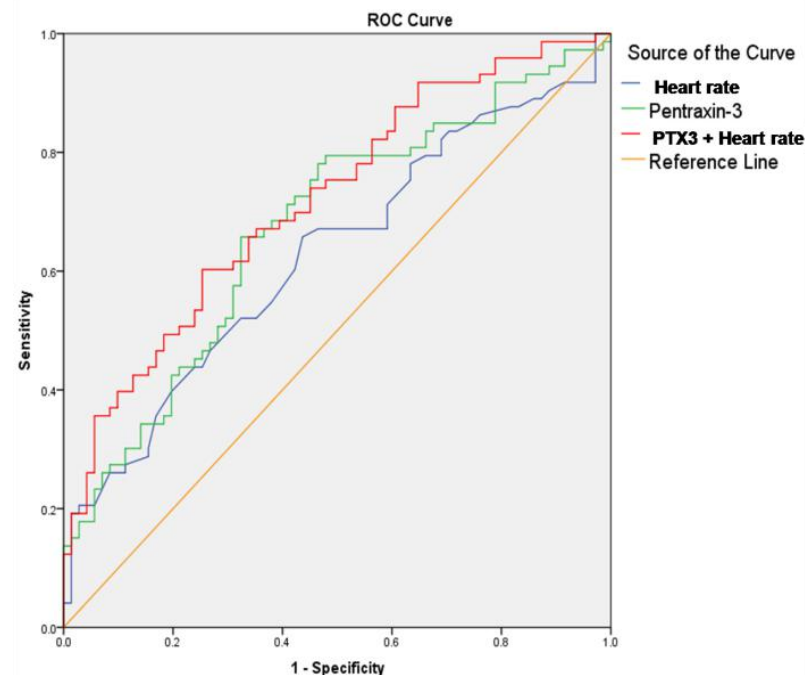

Figure 3. The ROC curve of PTX3, heart rate, and the combination of PTX3 with heart rate

Table 5.

AUC values of the PTX3 ROC curve, heart rate, and the combination of PTX3 with heart rate

\begin{tabular}{l|l|l|l}
\hline Variable & AUC value $(\%)$ & $\mathrm{p}$ & $95 \% \mathrm{CI}$ \\
\hline PTX3 & 67.4 & 0.001 & $0.586-0.762$ \\
Heart rate & 62.4 & 0.009 & $0.535-0.718$ \\
PTX3+ Heart rate & 71.9 & $<0.001$ & $0.637-0.801$ \\
\hline
\end{tabular}

Furthermore, patients were divided into two groups based on PTX3 levels, namely high PTX3 levels ( $\geq 8.247 \mathrm{ng} / \mathrm{mL}$ ) and low PTX levels $(<8.247 \mathrm{ng} / \mathrm{mL})$. The critical value of $8.247 \mathrm{ng} / \mathrm{mL}$ in this study was obtained based on the intersection of the PTX3 receiver operating characteristic (ROC) curve (presented in supplementary data 2) in predicting MACE during hospitalization which has optimal sensitivity and specificity values, which are $65.8 \%$ and $67.6 \%$ respectively.

Analysis to determine differences in MACE in groups with high and low PTX3 levels is described in Table 6. Obtained a significant difference in MACE events during hospitalization between groups with PTX3 levels $\geq 8.247$ and <8.247 ng / mL (p <0.001). At 3 months of observation, there was no significant difference in MACE between groups of patients with high and low PTX3 levels.

To find out the differences in survival between patients with high PTX3 levels ( $\geq 8.247 \mathrm{ng} / \mathrm{mL}$ ) and low $(<8.247$ ng / mL), a Kapplan-Meier curve analysis was performed. At the time of hospitalization, MACE was more frequently observed in the group with high PTX3 levels compared to low PTX3 with a hazard ratio (HR) 2.142 (95\% CI 1.315$3.487 ; \mathrm{p}=0.002$ ). This was not found in the 3 -month observation where there were no significant differences in survival between groups with high and low PTX 3 levels (Figure 4).
Table 6.

Comparison of MACE based on PTX3 levels

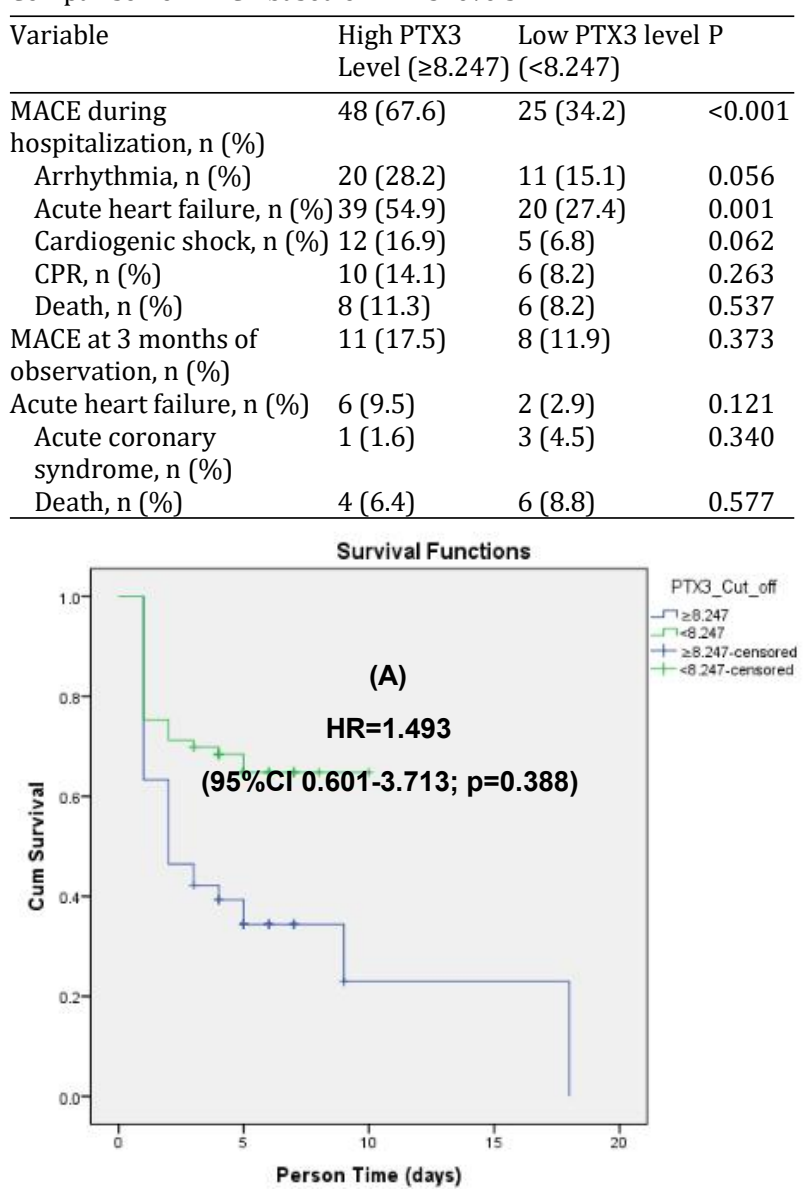

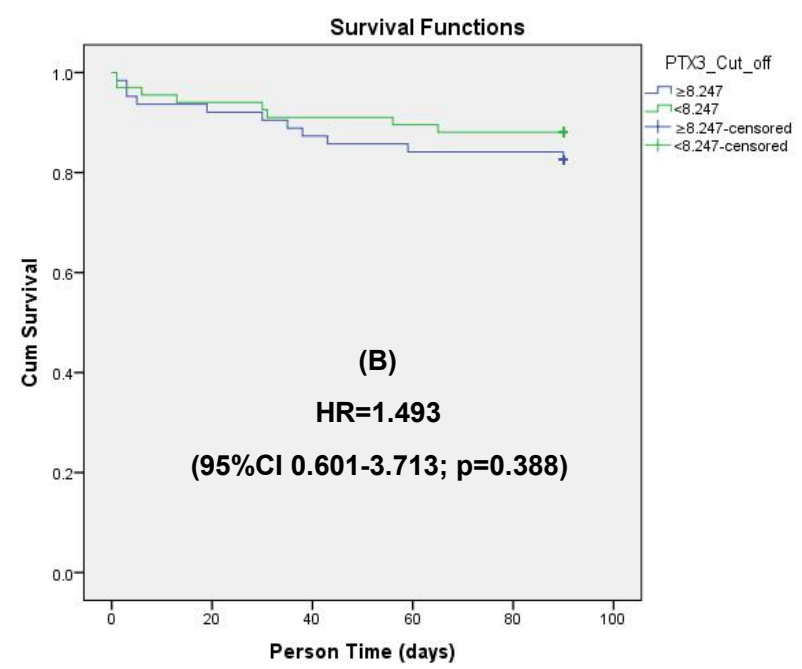

Figure 4. Kapplan-Meier curves showing the survival between patients with high and low PTX3 levels on the occurrence of MACE during hospitalization (A) and three months of observation (B) 


\section{Discussion}

PTX3 is an acute phase immune protein because it plays a role in innate immunity. This biomarker is released by polymorphonuclear neutrophils, macrophages, and vascular endothelium. ${ }^{20}$ PTX3 also triggers cardiovascular disease. ${ }^{21,22,23}$ Arterial atherosclerosis produces high levels of PTX3, mainly from macrophages and endothelial cells. In addition, oxidized LDL cholesterol stimulates the production of PTX3 by smooth muscle cells in plaque. ${ }^{24,25}$ In turn, PTX3 will activate the complement system and have the next chemotaxis effect. ${ }^{26,27}$ Because macrophages and vascular cells are the main cells recruited by the intestinal lining of the arteries during the atherosclerosis process, and because these cells are known to release PTX3, various studies have investigated PTX3 as a modulator of vascular damage. PTX3 is expressed by cardiomyocytes in resting conditions and will increase in the initial condition of ischemia, both in mice and in humans. ${ }^{28,29}$ In patients with AMI, peak PTX3 levels in plasma are 6-8 hours after the onset of chest pain and return to baseline levels within 3 days. ${ }^{30,31}$

Until now there has been no normal range of PTX3 values that are considered universally applicable. Examination of PTX3 levels in 100 healthy control subjects by Guo et al. (2013) obtained the upper limit from the mean \pm 2 standard deviations are $3.0 \mathrm{mg} / \mathrm{mL}$. Meanwhile, Altay et al. (2017) obtained a lower normal PTX3 value in 60 healthy control subjects $(0.86 \pm 0.5 \mathrm{ng} / \mathrm{mL})$. Peri et al. (2000); Inoue et al. (2007); Yamasaki et al. (2009); and Ristagno et al. (2019) obtained PTX3 levels $\leq 2 \mathrm{ng} / \mathrm{mL}$ in healthy subjects. In this study, there is an enhancement in PTX3 levels in patients with acute myocardial infarction when compared tonormal levels from previous studies with the distribution of data $8.16(0.21-69.35) \mathrm{ng} / \mathrm{mL}$ at the onset of chest pain in the first 24 hours. This finding is suitable with previous research by Peri et al. (2000), Latini et al. (2004), Guo et al. (2013), Akgul et al. (2015), Altay et al. (2017), and Eggers et al. (2013) who received an increase PTX3 levels acutely in patients with AMI both STEMI and NSTEMI. In this study also obtained comparable PTX3 levels in the STEMI and NSTEMI groups (8.16 (0.88-50.01) ng / mL vs 7.29 (0.21-69.35) ng / mL; $\mathrm{p}$ $=0.644)$. This is similar to the findings of Altay et al. (2017) who also did not get a significant difference in PTX3 levels between the STEMI and NSTEMI groups of 160 patients studied.

Also, there are some variations in the definition of MACE in several previous studies that tested the role of PTX3 levels in patients with acute myocardial infarction. Guo et al. (2014) in a retrospective cohort study that followed up on hospitalization and 30 days later defined MACE as recurrence of acute myocardial infarction, unstable angina pectoris, and target vessels revascularization. Qiu et al. (2017) in a prospective cohort study with a 3-month follow-up defining MACE as nonfatal acute myocardial infarction or heart failure, and death, similar to Mjelva et al. (2016) who followed up for 2 years and who followed up for 6 months. Akgul et al. (2015) followed up during hospitalization and the next 2 years observed reinfarction events, target vessel revascularization, stroke, CPR, hemodialysis, inotropic use, use of intra-aortic balloon pump (IABP), use of temporary pacemakers, atrial fibrillation, and mortality that happened. In this study, MACE observed during hospitalization was death due to cardiac causes, acute heart failure, cardiogenic shock, arrhythmias in the form of sustained ventricular tachycardia, ventricular fibrillation, new atrial fibrillation, and cardiopulmonary resuscitation, while MACE observed in the 3-month observation period was death, acute heart failure, and acute coronary syndromes that require rehospitalization.

In this study, there was a difference in MACE during hospitalization, with significantly higher PTX3 levels in the group that occurred MACE based on bivariate analysis (9.39 (21-69.35) vs $4.69(0.88-21.17), p<0.001)$. In multivariate analysis, it was also obtained that high PTX3 was a predictor of MACE during hospitalization with an odds ratio (Odd Ratio [OR]) of 1.127 ( $\mathrm{p}=0.001$ ). Research conducted by Brugger-Andersen et al. (2009), Guo et al. (2004), Qiu et al. (2017), Altay et al. (2017) is consistent with this result. Likewise, the meta-analysis by Chu et al. (2019) found that high PTX3 levels increased the risk of MACE (RR 1.62; CI 1.06-2.49) and increased the risk of death due to cardiac causes (RR 1.77; CI 1.38-2.26). The higher MACE in this and other studies may reflect the role of PTX3 in the pathogenesis of tissue damage (through amplification of the complement cascade and coagulation)32 as well as a protective response from PTX3 which is increased due to severe cardiac injury. ${ }^{13}$

In this study, a ROC curve analysis was performed to evaluate the value of PTX3 discrimination in predicting MACE. Based on the ROC curve it was found that PTX3 had an AUC of $67.4 \%$ ( $p<0.001 ; 95 \%$ CI $0.586-0.762$ ) to predict MACE during hospitalization. Research by Altay et al. (2017) found that PTX3 had an AUC of 75.6\% (95\% CI $0.647-0.864)$ in the STEMI group and $94.1 \%(95 \% \mathrm{CI}$ $0.878-1.004$ ) in the NSTEMI group in predicting MACE.

Besides, this study also found that heart rate affected the incidence of MACE during hospitalization based on bivariate analysis $(p=0.009)$ and multivariate (OR 1.025; $\mathrm{p}=0.015 ; 95 \%$ CI 1.005-1.046). After analyzing the ROC curve it was also found that combining PTX3 with heart rate produced a better diagnostic profile with AUC 71.9\% ( $p<0.001 ; 95 \%$ CI $0.637-0.801$ ) to predict MACE during hospitalization. This finding is in accordance with studies that found a faster heart rate in patients with higher levels of PTX3 than lower ( $86 \pm 25$ vs $76 \pm 20$, p $=0.003$ ) and in the group of patients with MACE compared without MACE $(92 \pm 29$ vs $79 \pm 22, p=0.06)$. Tomandlova et al. (2015) who also obtained results that heart rate affected the incidence of MACE based on multivariate analysis (OR $1.030 ; \mathrm{p}=0.008 ; 95 \%$ CI 1.008-1.054). The effect of increased heart rate on prognosis has been validated in patients with myocardial infarction as demonstrated in the Coronary Artery Surgery Study and BEAUTIFUL (Morbidity-mortality evaluation of the If inhibitors in Patients with Coronary Disease and Left Ventricular Dysfunction) which showed a positive association 
between increased heart rate and cardiovascular mortality. A meta-analysis of GISSI-2 and 3 studies involving 20,000 respondents showed that hospital mortality in post-IMA patients increased significantly from $3.3 \%$ to $10.1 \%$ when compared between patients with a pulse of 60 beats per minute with more than 100 times per minute. ${ }^{33}$

In this study, the critical value of discrimination determined to classify PTX3 levels in predicting MACE to be high and low is $8.247 \mathrm{ng} / \mathrm{mL}$ with a sensitivity of $65.8 \%$ and specificity of $67.6 \%$. Based on the cut-off analysis of the ROC curve, the PTX3 content showed that PTX3 levels were considered high if $\geq 8.247 \mathrm{ng} / \mathrm{mL}$ and low when $<8.247 \mathrm{ng} / \mathrm{mL}$ and there were significant MACE differences in the two groups during hospitalization ( $p$ $<0.001$ ). Several previous studies on the subject of acute myocardial infarction both STEMI and NSTEMI established different definitions of the cut-off that were thought to affect MACE. Akgul et al. (2015) divides PTX3 levels into high if they have values above the 3rd tertile value of PTX3 levels in the study subjects (high $\geq 3.2 \mathrm{ng} / \mathrm{mL}$; low $<3.2 \mathrm{ng} / \mathrm{mL}$ ). Other researchers who designate the 3rd tertile as a high PTX3 level are Latini et al. (2004) (> 10.73 $\mathrm{ng} / \mathrm{mL}$ ); Altay et al. (2017) ( $\geq 4.27 \mathrm{ng} / \mathrm{mL})$, and Qiu et al. (2017) ( $\geq 6.9 \mathrm{ng} / \mathrm{mL}$ ). Mjelva et al. (2016) determined high PTX3 levels if they had values above the 4th quartile value (> $9.5 \mathrm{ng} / \mathrm{mL}$ ). While Guo et al. (2014) determined that PTX3 levels were higher when more than upper limit from the mean \pm 2 standard deviations of healthy control subjects (> $3.0 \mathrm{mg} / \mathrm{mL})$. There are variations in determining PTX3 levels which are considered high in predicting MACE. The Kapplan-Meier curve to assess the occurrence of MACE during hospitalization shows that groups with high PTX3 levels compared to low PTX3 have a hazard ratio (HR) of 2.142 (95\% CI 1.315-3.487; p = 0.002) which means groups with high PTX3 levels occur more quickly by 2.142 times than in the group with low PTX3 levels. Research by Kontny et al. (2019) found findings similar to HR per 50\% increase in PTX3 levels was 1.13 (1.07-1.19).

At 3 months observation, there was no difference in PTX3 between groups with MACE and without MACE in the bivariate analysis $(p=0.408)$. In addition, MACE between groups with high and low PTX3 levels was also not significantly different $(0=0.373)$. In the survival analysis, there was also no MACE difference in the Kapplan-Meier curve $(p=0.388)$. Some alternative explanations for this are due to the lack of sample size, drop out of the analysis in patients who die during hospitalization, the use of PTX3 cut-off points which are considered high or low based on the value at the hospitalization, or the lack of time to observe MACE. Among the many studies that tried to link PTX3 levels with MACE, there were also studies that did not find differences in PTX3 levels between groups with MACE and without MACE, namely, research conducted by George et al. (2015) in 160 STEMI, NSTEMI, and UAP patients observed for 6 months.

\section{Limitation}

There are several limitations to this study. First, the study was conducted at a single centre. Second, MACE observations were only made during hospitalization and 3 months of observation. Third, primary percutaneous coronary intervention (PCI) for both STEMI and initial invasive strategies ( $<24$ hours) or immediately ( $<2$ hours) in high and very high-risk NSTEMI patients neither still fully implemented in our centre nor analyzed in this study which might be can affect the incidence of MACE. Fourth, PTX3 levels were only measured at admission. We did not take serial measurements so we could not evaluate changes in PTX3 levels to treatment.

\section{Conclusion}

There is a difference in major cardiovascular events between patients with high and low PTX3 levels at the time of hospitalization in IMA patients with a cut-off value of $8.247 \mathrm{ng} / \mathrm{mL}$. At three months of observation, there were no significant differences in major cardiovascular events between patients with high and low PTX3 levels.

\section{Acknowledgement}

The authors are grateful to Imelda Christina, MD for his permission to continue her previous study.

\section{Funding Sources}

The grant of the research was from The Indonesian Endowment Fund for Education, Indonesian Ministry of Finance to A.B.

\section{References}

1. Benjamin EJ, Virani SS, Callaway CW, Chamberlain AM, Chang AR, Cheng S, et al. 2018. Heart Disease and Stroke Statistics-2018 Update: A Report from the American Heart Association Circulation, 137:e67-e492.

2. Dharma S, Andriantoro H, Purnawan I, Dakota I, Basalamah F, Hartono B, et al. 2016. Characteristics, treatment and in-hospital outcomes of patients with STEMI in a metropolitan area of a developing country: an initial report of the extended Jakarta Acute Coronary Syndrome registry. BMJ Open, 6:e012193.

3. Wasyanto T, Tridamayanti, A. 2019. Blood urea nitrogen as predictor of In-hospital mortality in acute coronary syndrome patients. Indonesian $\mathrm{J}$ of Med, 4:241-251

4. Presta M, Camozzi M, Salvatori G, Rusnati M. 2007. Role of the soluble pattern recognition receptor PTX3 in vascular biology. J Cell Mol Med, 11:723-738.

5. Norata GD, Garlanda C, Catapano AL. 2010. The long pentraxin PTX3: a modulator of the immunoinflammatory response in atherosclerosis and cardiovascular diseases. Trends Cardiovasc Med, 20:35-40. 
6. Casula M, Montecucco F, Bonaventura A, Liberale L, Vecchie A, Dallegri F, et al. 2017. Update on the role of Pentraxin 3 in atherosclerosis and cardiovascular diseases. Vascul Pharmacol, 99:1-12.

7. Rusnati M, Camozzi M, Moroni E, Bottazzi B, Peri G, Indraccolo $S$, et al. 2004. Selective recognition of fibroblast growth factor-2 by the long pentraxin PTX3 inhibits angiogenesis. Blood, 104:92-99.

8. Yahia M, Elmasry OS, Ra'ouf MA. 2018. The Relationship between Serum Pentraxin-3 Levels and Severity of Coronary Heart Disease. World Journal of Cardiovascular Diseases, 8:370-380.

9. Soeki T, Niki T, Kusunose $\mathrm{K}$, Bando S, Hirata $\mathrm{Y}$, Tomita N, et al. 2011. Elevated concentrations of pentraxin 3 are associated with coronary plaque vulnerability. J Cardiol, 58:151-157.

10. Hamad RR, Eriksson MJ, Berg E, Larsson A, Bremme K. 2012. Impaired endothelial function and elevated levels of pentraxin 3 in early-onset preeclampsia. Acta Obstet Gynecol Scand, 91:50-56.

11. Ustündağ M, Orak M, Güloğlu C, Sayhan MB, Alyan O, Kale E. 2011. Comparative diagnostic accuracy of serum levels of neutrophil activating peptide- 2 and pentraxin-3 versus troponin-I in acute coronary syndrome. Anadolu Kardiyol Derg, 11:588-594.

12. Matsui S, Ishii J, Kitagawa F, Kuno A, Hattori K, Ishikawa $\mathrm{M}$, et al. 2010. Pentraxin 3 in unstable angina and non-ST-segment elevation myocardial infarction. Atherosclerosis, 210:220-225.

13. Ristagno G, Fumagalli F, Bottazzi B, Mantovani A, Novelli D, Latini R. 2019. Pentraxin 3 in Cardiovascular Disease. Front Immunol, 10:823.

14. Ibanez B, James S, Agewall S, Antunes MJ, BucciarelliDucci C, Bueno H, et al. 2017. 2017 ESC Guidelines for the management of acute myocardial infarction in patients presenting with ST-segment elevation: The Task Force for the management of acute myocardial infarction in patients presenting with STsegment elevation of the European Society of Cardiology (ESC). Eur Heart J, 39:119-177.

15. O'Gara PT, Kushner FG, Ascheim DD, Casey DE, Chung MK, De Lemos JA, et al. 2013. 2013 ACCF/AHA guideline for the management of ST-elevation myocardial infarction: executive summary: a report of the American College of Cardiology Foundation/American Heart Association Task Force on Practice Guidelines. J Am Coll Cardiol, 61:485510.

16. Roffi M, Patrono C, Collet JP, Mueller C, Valgimigli M, Andreotti F, et al. 2015. ESC guidelines for the management of acute coronary syndromes in patients presenting without persistent ST-segment elevation. Eur Heart J, 37:267-315.

17. Akgul O, Baycan OF, Bulut U, Somuncu MU, Pusuroglu H, Ozyilmaz S, et al. 2015. Long-term prognostic value of elevated pentraxin 3 in patients undergoing primary angioplasty for ST-elevation myocardial infarction. Coron Artery Dis, 26:592-597.

18. Guo R, Li Y, Wen J, Li W, Xu Y. 2014. Elevated plasma level of pentraxin-3 predicts in-hospital and 30-day clinical outcomes in patients with non-ST-segment elevation myocardial infarction who have undergone percutaneous coronary intervention. Cardiology, 129:178-188.

19. Dahlan MS. 2013. Statistik untuk kedokteran dan kesehatan. Edisi 6. Jakarta: Salemba Medika. p.33-42

20. Mantovani A, Garlanda C, Doni A, Bottazzi B. 2008. Pentraxins in innate immunity: from C-reactive protein to the long pentraxin PTX3. J Clin Immunol, 28:1-13.

21. Willerson JT, Ridker PM. 2004. Inflammation as a cardiovascular risk factor. Circulation, 109(21 Suppl 1):II2-II10.

22. Latini R, Maggioni AP, Peri G, Gonzini L, Lucci D, Mocarelli P, et al. 2004. Prognostic significance of the long pentraxin PTX3 in acute myocardial infarction. Circulation, 110:2349-2354.

23. Inoue K, Sugiyama A, Reid PC, Ito Y, Miyauchi K, Mukai S, et al. 2007. Establishment of a high sensitivity plasma assay for human pentraxin 3 as a marker for unstable angina pectoris. Arterioscler Thromb Vasc Biol, 27:161-167.

24. Rolph MS, Zimmer S, Bottazzi B, Garlanda C, Mantovani A, Hansson GK. 2002. Production of the long pentraxin PTX3 in advanced atherosclerotic plaques. Arterioscler Thromb Vasc Biol, 22:e10-e14.

25. Zacho J, Tybjærg-Hansen A, Nordestgaard BG. 2010. C-reactive protein and all-cause mortality-the Copenhagen City Heart Study. Eur Heart J, 31:16241632.

26. Klouche M, Peri G, Knabbe C, Eckstein HH, Schmid FX, Schmitz G, et al. 2004. Modified atherogenic lipoproteins induce expression of pentraxin-3 by human vascular smooth muscle cells. Atherosclerosis, 175:221-228.

27. Savchenko AS, Imamura $M$, Ohashi $R$, Jiang $S$, Kawasaki T, Hasegawa G, et al. 2008. Expression of pentraxin 3 (PTX3) in human atherosclerotic lesions. J Pathol, 215:48-55..

28. Maugeri, N., Rovere-Querini, P., Slavich, M., Coppi, G., Doni, A., Bottazzi, B., et al. 2011. Early and transient release of leukocyte pentraxin 3 during acute myocardial infarction. J Immunol, 187:970-979.

29. Kunes P, Holubcova Z, Kolackova M, Krejsek J. 2012. Pentraxin 3(PTX 3): an endogenous modulator of the inflammatory response. Mediators Inflamm, 2012:920517.

30. Peri G, Introna M, Corradi D, Iacuitti G, Signorini S, Avanzini F, et al. 2000. PTX3, A prototypical long 
pentraxin, is an early indicator of acute myocardial infarction in humans. Circulation, 102:636-641.

31. Helseth R, Solheim S, Opstad T, Hoffmann P, Arnesen H, Seljeflot I. 2014. The time profile of Pentraxin 3 in patients with acute ST-elevation myocardial infarction and stable angina pectoris undergoing percutaneous coronary intervention. Mediators Inflamm, 2014:608414.

32. Napoleone E, Di Santo A, Peri G, Mantovani A, De Gaetano G, Donati MB, Lorenzet R. 2004. The long pentraxin PTX3 up-regulates tissue factor in activated monocytes: another link between inflammation and clotting activation. J Leukoc Biol, 76:203-209.

33. Custodis F, Reil JC, Laufs U, Böhm M. 2013. Heart rate: a global target for cardiovascular disease and therapy along the cardiovascular disease continuum. J Cardiol, 62:183-187 